Notre Dame Law Review

Volume 75

Issue 5 Propter Honoris Respectum

Article 2

$8-1-2000$

\title{
On the Dividing Line between Natural Law Theory and Legal Positivism
}

Brian Bix

Follow this and additional works at: http://scholarship.law.nd.edu/ndlr

\section{Recommended Citation}

Brian Bix, On the Dividing Line between Natural Law Theory and Legal Positivism, 75 Notre Dame L. Rev. 1613 (2000).

Available at: http://scholarship.law.nd.edu/ndlr/vol75/iss5/2

This Article is brought to you for free and open access by NDLScholarship. It has been accepted for inclusion in Notre Dame Law Review by an authorized administrator of NDLScholarship. For more information, please contact lawdr@nd.edu. 


\title{
ON THE DIVIDING LINE BETWEEN NATURAL LAW THEORY AND LEGAL POSITIVISM
}

\author{
Brian Bix*
}

John Finnis has been for over twenty years one of the most prominent and important advocates for, and defenders of, natural law theory. ${ }^{1}$ Natural law theory is a broad tradition; within that broad tradition, Finnis occupies a somewhat controversial and arguably outsider's position. ${ }^{2}$ Most law students come across natural law theory, not in its usual form as a centuries-old way of thinking about morality, theology, and politics, but rather in its more modest and modern guise as a theory competing with legal positivism for the proper description and analysis of law. ${ }^{3}$ While this entry onto natural law theory may only serve to invite certain misunderstandings of natural law's larger project, the continuing prominence of this perspective in law schools and law reviews-seeing natural law mostly as an opponent of legal positivism-requires that we not ignore this "debate." Certainly Finnis has not ignored the "debate"; to the contrary, his work has offered many provocative ways of rethinking and recasting the lines of battle. This Article considers the points of agreement and disagreement between natural law theory and legal positivism, with particular emphasis on Finnis's views of the "debate" and his contributions to it.

* Visiting Professor of Law, Georgetown University Law Center; Professor of Law, Quinnipiac College School of Law. I am grateful to Matthew D. Adler, Lawrence E. Mitchell, Thomas H. Morawetz, Joseph Raz, Brian Z. Tamanaha, and Robert W. Tuttle for their comments and suggestions.

1 See John Finnis, Natural Law and Natural Rights (1980).

2 See, e.g., Russell Hrttinger, A Critique of the New Natural Law Theory (1987) (criticizing the approach to natural law developed by Germain Grisez and Finnis from the perspective of traditional Thomistic natural law); Russell Hittinger, Varieties of Minimalist Natural Law Theory, 34 AM. J. JuRIs. 133 (1989) (same).

3 For an overview of natural law theory and the place of natural law legal theories within that larger context, see Brian Bix, Natural Law Theory: The Modern Tradition, in Handbook of Jurisprudence and Legal Philosophy (Jules L. Coleman \& Scott Shapiro eds., forthcoming 2000), available in Social Science Research Network Electronic Library (last modified Dec. 12, 1999) <http://papers.ssrn.com/paper.taf?ABSTRACT_ $\mathrm{ID}=199928>$. 
Part I considers some threshold methodological difficulties with the inquiry. Part II considers a conventional understanding of the boundary lines between natural law theory and legal positivism, noting how many recent writers, Finnis included, have concluded that the two schools of thought may be, in these matters at least, compatible. Part III follows the lead of Finnis's more recent work and looks for significant differences of perspective elsewhere, in a potential debate over the basic value or viability of the legal positivist enterprise.

\section{Dangers of Discussing Schools of Thought}

There is one preliminary concern. Joseph Raz has described the dangers in talking about the views of a particular school of thought:

$[\mathrm{O}]$ ne of the unattractive tendencies of contemporary legal and political philosophy [is where a commentator] does not discuss anyone's views, but a family of views. This allows one to construct one's target by selecting features from a variety of authors so that the combined picture is in fact no one's view, and all those cited as adhering to it would disagree with it. ${ }^{4}$

The dangers must double when one is comparing two different schools of thought, here natural law theory and legal positivism. Yet most academics persist in talking about "schools of thought" or "movements," in part because we are invited to do so by the theorists themselves, many of whom broadly proclaim their affiliations (as well as the group, or group of claims, at which their criticisms are targeted), and in part because life just becomes too complicated if one cannot discuss individual views or events as the instance of a larger group. The trick is to try to make sure that the group one is describing is not just the "straw man" Raz warns us about-that there is at least one major theorist willing to affirm all the views attributed to the category described. This Article will refer to "legal positivism" and "natural law theory" as schools of thought, but will try to do so in a way which respects the diversity within those titles and does not create in the name of those groups a fictional, weak hybrid view, which no existing or past legal theorist would actually advocate.

\section{The Conventional View of the Boundary Line}

To summarize, briefly and a bit crudely, natural law theory considers the connections between the universe, human nature, and morality, usually deriving the last from some combination of the first

4 Joseph Raz, Postema on Law's Autonomy and Public Practical Reasons: A Critical Comment, 4 Legal Theory 1, 1 (1998). 
two. 5 The majority position within the natural law tradition appears to be that moral truths are to be derived from truths about human nature. A minority position in the tradition, represented by, among others, Finnis, Germain Grisez, and Robert George, is that moral truths are to be discovered or derived in other ways (though these truths are connected with truths about human nature, they are not derived from such truths). ${ }^{6}$ The difference can be crucial for those attempting to avoid an allegedly improper derivation of an "ought" from an "is." Natural law theory discussions of human positive law tend to focus on moral obligations: what laws should a (good) legislator pass, and when does a (good) citizen have a moral obligation to obey the law. ${ }^{8}$

Legal positivism is the belief that it is both tenable and valuable to offer a purely conceptual and/or purely descriptive theory of law, ${ }^{9}$ in which the analysis of law is kept strictly separate from its evalua-

5 See, e.g., Yves R. Simon, The Tradition of Natural Law: A Philosopher's ReFlections 41-66 (Vukan Kuic ed., 1965); Lloyd L. WeINREB, Natural LAW aND Justice 1-2 (1987) (discussing the connections between nature, law, and morality in classical natural law theory); Bix, supra note 3, at 1-18.

6 See Robert P. George, In Defense of Natural Law 83-87 (1999) (summarizing the dispute).

7 See Finnis, supra note 1, at 33-36 (responding to the "is/ought" challenge).

8 See, e.g., Saint Thomas Aquinas, The Treatise on Law (R.J. Henle ed. \& trans., 1993) (offering a translation of sections of the Summa Theologiae that discuss law); FinNIS, supra note 1, at 260-96.

9 Some writers within legal positivism view theories of law (compatible with that approach) as conceptual and non-evaluative, but not descriptive (in the narrowest sense of that term). One prominent example is Joseph Raz:

Since law belongs to the executive stage [of practical decisionmaking], it can be identified without resort to moral arguments, which belong by definition to the deliberative stage. The doctrine of the nature of law yields a test for identifying law the use of which requires no resort to moral or any other evaluative argument. But it does not follow that one can defend the doctrine of the nature of law itself without using evaluative (though not necessarily moral) arguments. Its justification is tied to an evaluative judgment about the relative importance of various features of social organizations, and these reflect our moral and intellectual interests and concerns.

Joseph Raz, Ethics In the Public Domain: Essays in the Morality of Law and PolitICs 209 (1994); see also Joseph Raz, Two Views of the Nature of the Theory of Law: A Partial Comparison, 4 LEGAL THEORY 249, 267-68 (1998) (summarizing Raz's disagreement with H.L.A. Hart regarding whether Hart's legal positivistic theory is descriptive or evaluative). But see H.L.A. HART, The ConcePt OF LAw 239 (2d ed. 1994) ("My aim in this book was to provide a theory of what law is which is both general and descriptive."). 
tion. ${ }^{10}$ Modern legal positivism developed in reaction to certain (less sophisticated) versions of natural law theory. John Austin was reacting to some clumsy natural law references in the work of Sir William Blackstone when he wrote what has become perhaps the most frequently cited summary of legal positivistic "dogma":

The existence of law is one thing; its merit or demerit is another. Whether it be or be not is one enquiry; whether it be or be not conformable to an assumed standard, is a different enquiry. A law, which actually exists, is a law, though we happen to dislike it, or though it vary from the text, by which we regulate our approbation and disapprobation. ${ }^{11}$

In a recent provocative essay, Finnis concedes that there were some basic truths to legal positivism, but most of them had been articulated, at least in rough form, hundreds of years ago by a theorist best known for his development of natural law theory: Thomas Aquinas. ${ }^{12}$ Finnis attributes to Aquinas the move "of taking human positive law as a subject of consideration in its own right (and its own name), a topic readily identifiable and identified prior to any question about its relation to morality." 13 For Finnis, as for Aquinas, positive law has a role within moral thought and moral practice. Positive law (at least generally just positive law) plays a crucial role in achieving so$\mathrm{cial} /$ common goods that require the deployment of state power (for example, sanctions for criminal behavior) or the coordination of citizen action. ${ }^{14}$

10 See generally Brian Bix, Jurisprudence: Theory And ConText 31-49 (2d ed. 1999) (discussing Hart and legal positivism); THE AutonOMY OF LAW: Essays ON LEgal Positrvism (Robert P. George ed., 1996) [hereinafter The Autonomy of LAw]; Jules L. Coleman \& Brian Leiter, Legal Positivism, in A Companion to Philosophy of Law and Legal Theory 241 (Dennis Patterson ed., 1996).

11 John Austin, The Province of Jurisprudence Determined 157 (Wilfrid E. Rumble ed., Cambridge Univ. Press 1995) (1832). The Blackstone quotation to which Austin was responding appears in 1 WILLIAM BLAckstone, COMMENTARIES ON THE LAws OF ENGLAND 41 (University of Chicago Press 1979) (1765). For a sympathetic discussion of Blackstone's natural law views, see J.M. Finnis, Blackstone's Theoretical Intentions, 12 NAT. L.F. 163 (1967).

12 See John Finnis, The Truth in Legal Positivism, in The Autonomy of Law, supra note 10, at 195, 195.

13 Id. at 204.

14 See, e.g., FinNis, supra note 1, at 260-64 (discussing criminal law); John Finnis, The Authority of Law in the Predicament of Contemporary Social Theory, 1 NOTRE DAME J.L. ETHICs \& Pub. PoL'y 115, 117-21 (1984) (same); John M. Finnis, Law as Co-ordination, 2 RATIO JuRIs 97, 101-03 (1989) (discussing the importance of law for social coordination). 
There appears to be a sense in which (an important and welltraveled branch of) natural law theory and legal positivism are compatible, in the sense that one's position on the first does not determine one's position on the second. If what makes one a natural law theorist is adherence to a certain kind of metaphysical realism about morality ${ }^{15}$-natural law theorists seem to agree that moral realism is an important component of the tradition, but disagree on the extent to which the tradition requires other significant commitments ${ }^{16}$ - that meta-ethical belief (moral realism) seems to be consistent with a variety of views about the (conceptual) connection between law and morality. ${ }^{17}$

Similarly, if (1) natural law theory reduces to the claim that there is objective moral truth, and that this truth should be used to evaluate our political and legal institutions as well as our individual choices, and (2) legal positivism reduces to the claim that there is a possibility of and value to a descriptive or conceptual theory of law separated from any evaluation of its (moral) merits, then there would seem no reason why one could not support or advocate both. Indeed, a number of prominent legal positivists and natural law theorists have so claimed at one time or another. ${ }^{18}$ One can find theorists who suggest that legal positivism entails opposing natural law's views on the exis-

15 "Moral realism" has been defined as "[ $\mathrm{t}]$ he view that moral beliefs and judgements can be true or false, that there exist moral properties to which moral agents are attentive or inattentive, sensitive or insensitive, that moral values are discovered, not willed into existence nor constituted by emotional reactions." R.W. Hepburn, Moral Realism, in The Oxford Companion to Philosophy 596 (Ted Honderich ed., 1995).

16 Compare John Finnis, Natural Law, in 6 Routledge Encrclopedia of PhilosoPHY 685 (1998) (emphasizing moral realism), with HrTTINGER, supra note 2, at 8 (denying that Finnis is within the natural law tradition because his theory does not view "nature as in some way normative"), and WEINREB, supra note 5, at 97 (equating natural law with an objective approach to morality that is ontologically based).

17 See Michael S. Moore, Law as a Functional Kind, in NATURAL Law ThEOrY: CoNTEMPORARY Essays 188, 192 (Robert P. George ed., 1992) [hereinafter Natural Law THEORY].

18 See, e.g., H.L.A. Hart, Essays In Jurisprudence and Philosophy 10 (1983) (describing Finnis's natural law theory as being "in many respects complementary to rather than a rival of positivist legal theory"); Neil MacCormick, Natural Law and the Separation of Law and Morals, in NATURAL LAw THEORY, supra note 17, at 105, 109 (describing the convergences of modern legal positivism and Finnis's natural law theory); Joseph Raz, The Morality of Obedience, 83 MrcF. L. REv. 732, 739 (1985) (book review) (claiming that "it is a mistake to think that the legal positivist and the natural law traditions are inherently incompatible"). 
tence of (objective) moral truths, ${ }^{19}$ but such theorists are distinctly in the minority.

\section{Finnis's View of THE Boundary Line}

The great legal positivists-whether John Austin responding to Sir William Blackstone, ${ }^{20}$ H.L.A. Hart in his debate with Lon Fuller, ${ }^{21}$ or Hans Kelsen putting forward a "pure" theory of law22 - saw themselves as reacting against natural law theory. Were they wrong? Were all the commentators writing about the "debate" between natural law theory and legal positivism deluded into imagining disagreements where there are in fact no disagreements to be found, let alone argued over? ${ }^{23}$

It may be that the boundary lines and battle lines between legal positivism and natural law theory are to be drawn elsewhere than is conventionally thought. In an early and classic text, Finnis suggests one place to relocate the debate: in the small and seemingly insignificant details of theory construction. ${ }^{24}$

Finnis suggests a modification to an argument first put forward by the legal positivist H.L.A. Hart. Hart had offered an important development of legal positivism in particular, and of legal theory in general, when he argued that theories of law should take into account, and indeed be built around, the perspective of a participant in the legal system-to be grounded on the meaning that aspects of the sys-

19 See, e.g., Alf Ross, Validity and the Conflict Between Legal Positivism and Natural Law, in Normatrvtry and Norms: Critical. Perspegtives on Kelsenian Themes 147, 148-49 (Stanley L. Paulson \& Bonnie Litschewski Paulson eds., 1998).

20 See Austin, supra note 11, at 157-59; Blackstone, supra note 11.

21 See Lon L. Fuller, Positivism and Fidelity to Law-A Reply to Professor Hart, 71 Harv. L. Rev. 630 (1958); H.L.A. Hart, Positivism and the Separation of Law and Morals, 71 HARV. L. REv. 593 (1958).

22 See Hans Kelsen, Introduction to the Problems of Legal Theory 7-8 (Bonnie Litschewski Paulson \& Stanley L. Paulson trans., 1992) (defining "Pure Theory of the Law"); Hans Kelsen, The Idea of Natural Law, in Essays IN LEgal AND Moral PHILOSOPHY 27-60 (Peter Heath trans., 1973) (contrasting legal positivism and natural law theory).

23 As the rest of this Article indicates, I think there is a real debate between legal positivism and natural law theory. At the same time, one can reasonably conclude that some of the legal positivists had a faulty perception of the debate, based on caricatured views of natural law (caricatures which may have been encouraged by the less able exponents of that view, see e.g., Blackstone, supra note 11).

24 See FinNis, supra note 1 , at 3-18. 
tem have to those participants, as contrasted with taking the quasiscientific perspective of a complete outsider. ${ }^{25}$

Finnis agrees with the importance of constructing theory around an internal point of view, but he suggests amendments to the viewpoint selected by Hart. Hart uses the viewpoint of the participant who "accepts" the legal system, in the sense of using the legal rules as the criteria for guiding and appraising his own behavior and the behavior of others, ${ }^{26}$ but Hart took a broad view of the nature and motives of such "acceptance."27 Finnis suggests that this central viewpoint be narrowed to that of the participant (1) who is following the law because (and thus, only when) the law imposes (presumptive) moral obligations of obedience and (2) whose judgment on these subtle moral questions is good. 28

Finnis's proposed change to Hart's approach may seem a small one, but it is one of theoretical significance. For in Hart's version, the theorist is offering no judgments or evaluations of the moral worth of the practice (or of the participants); the theorist is merely describing. By contrast, in Finnis's version, theory construction requires moral evaluation. The line being crossed is one about separating law and morality. ${ }^{29}$

This small detail of theory construction returns us to what we should perhaps now treat as the central question: whether positive law

25 See HART, supra note 9, at 55-58, 82-99 (emphasizing the importance of an internal perspective in the course of analyzing habits, rules, and law); see also Brian Bix, H.L.A. Hart and the Hermeneutic Turn in Legal Theory, 52 SMU L. REv. 167 (1999).

26 See HART, supra note 9, at 98.

27 See id. at 203 ("[T] heir allegiance to the system may be based on many different considerations: calculations of long-term interest; disinterested interest in others; an unreflecting inherited or traditional attitude; or the mere wish to do as others do.").

28 See Finnis, supra note 1, at 9-15; see also John Frnnis, AQuinas: Moral, PolrtiCAL AND Legal Theory 257-58 (1998). In this text, Finnis states,

One "internalizes" the law when one willingly, promptly, readily-and not merely out of "extrinsic" motivations of fear of punishment or hope of reward-complies with its requirements, not only according to the letter of the law but primarily according to the lawmaker's intention and plan for common good. Such states of affairs are the central case of law because they most fully instantiate the fundamental notion of law: a prescription of reason, by means of which rational and indeed conscientious and reasonable practical judgments about the needs of a complete community's common, public good, having been made and published by lawmakers, are understood and adopted by citizens as the imperium of their own autonomous, individual practical reason and will.

Id. (citations omitted).

29 See Bix, supra note 25, at 184-86. 
can valuably be studied separately from moral considerations. Finnis's response is in the negative:

Though human law is artefact and artifice, and not a conclusion from moral premises, both its positing and the recognition of its positivity (by judges, professionals, citizens, and thence by descriptive and critical scholars) cannot be understood without reference to the moral principles that ground and confirm its authority or challenge its pretention. ${ }^{30}$

When Finnis writes that positive law "is . . not a conclusion from moral premises," emphasis must be laid on the term "is." Finnis, following Aquinas, argues that the moral lawmaker will discern what laws to promulgate largely by deduction or derivation from morality ("natural law"); in other words, morality is important in determining what the positive law should be. ${ }^{31}$ However, this is a far different claim from stating that one could use morality to determine or describe what the positive law of a particular legal system currently is.

Legal positivists usually present their dogma about the separation of law and morality in terms of separating the attribution of legality or legal validity from evaluation of (the legal rules' or legal system's) moral worth. ${ }^{32}$ This view of legal positivism, and of its difference from natural law theory, is connected to an equation (mostly by non-natural law lawyers) of natural law theory with the phrase, "lex iniusta non est lex"33_"an unjust law is not a law."34 Finnis wants to transform our discussions of legal positivism and the separation of law and morals. He urges that natural law theorists have never denied a disjunction

30 Finnis, supra note 12, at 205.

31 See FinNis, supra note 28, at 266-72; FinNIS, supra note 1, at 281-90; Finnis, supra note 12, at 196-203.

32 See, e.g., HART, supra note 18, at 55.

What both Bentham and Austin were anxious to assert were the following two simple things: first, in the absence of an expressed constitutional or legal provision, it could not follow from the mere fact that a rule violated standards of morality that it was not a rule of law; and, conversely, it could not follow from the mere fact that a rule was morally desirable that it was a rule of law.

Id; see also supra text accompanying note 11.

33 See, e.g., MacCormick, supra note 18, at 106 ("For long, the leading jurisprudential image of natural law theory presented it as defined by the thesis that unjust laws are necessarily non-laws.").

34 The expression is true, and indeed somewhat banal, when understood as saying that unjust laws are not laws "in the fullest sense," in that they do not create moral obligations to obey them in the way that just laws do. See Brx, supra note 10, at 64-66; FinNIS, supra note 1, at 363-66; Norman Kretzmann, Lex Iniusta Non Est Lex. Laws on Trial in Aquinas' Court of Conscience, 33 AM. J. Juris. 99 (1988). 
between positive law and moral merit and that lex iniusta, properly understood, never claimed the contrary. ${ }^{35}$

Finnis would urge that the more important aspect of the separation of law and morality is in the separation of legal theory and moral evaluation. The question legal positivism raises, as noted earlier, is whether a purely conceptual or descriptive theory of law is both tenable and valuable. ${ }^{36}$ Finnis's initial small-scale challenge regarding the best way to construct the "internal perspective" of a legal system can be seen as a challenge to the legal positivist position in this sense. If a theory that does not morally evaluate its internal perspective is markedly inferior to a theory that does, then a non-evaluative approach to law may be possible, but it is of little value.

The legal positivist response to the morality-centered criticism has often been to advocate the importance of the objective or (social) scientific perspective. In responding to another prominent critic of legal positivism, Ronald Dworkin, Hart puts forth the following argument:

[T] here is a standing need for a form of legal theory or jurisprudence that is descriptive and general in scope, the perspective of which is not that of a judge deciding "what the law is," that is, what the law requires in particular cases ... but is that of an external observer of a form of social institution with a normative aspect, which in its recurrence in different societies and periods exhibits many common features of form, structure, and content. ${ }^{37}$

Hart's point is that moral analysis within and about the law may be useful and important, but such importance does not negate the value of looking at the law from the point of view of social science.

However, it is important to note that while Dworkin may deny the value of a social science or social theory approach to law, ${ }^{38}$ it seems clear that Finnis does not oppose such an approach. He has made clear on a number of occasions that a "descriptive social science of

35 See FinNIs, supra note 1, at 363-66 (discussing lex iniusta); Finnis, supra note 12, at 203-04 (accepting the disjunction of legal validity and moral evaluation).

36 The phrasing "both tenable and valuable" is meant to respond to the possible view that a theory without significant moral evaluation might be possible, but it would be a theory of little value, significantly inferior to theories which have such moral content.

37 H.L.A. Hart, Comment, in Issues IN Contemporary Legal Philosophy: The INFLUENCE OF H.L.A. HART 35, 36 (Ruth Gavison ed., 1987).

38 Hart points out, "In his books Dworkin appears to rule out general and descriptive legal theory as misguided or at best simply useless." HART, supra note 9, at 242. 
law,"39 derived in part from Max Weber and Aristotle, facilitates a clear discussion of the nature of law. ${ }^{40}$ Finnis's complaint against Hart (and other legal positivists) is not that one should not attempt a general social theory of law, but rather that one should not expect such a theory to be non-evaluative.

Finnis's view is that law should be understood in connection with the (moral) ideal to which it is aspiring and the (moral) function it is intended to play. ${ }^{41}$ One cannot fully understand a reason-giving activity unless one understands what it would take to make something a good reason for action. ${ }^{42}$ This approach to law could be understood as teleological, at least in a broad or metaphoric sense of the term. ${ }^{43}$ In pressing this approach to law, Finnis is well within the mainstream of

39 FinNis, supra note 1 , at 3.

40 See id. at 3-19; John M. Finnis, Law, Problems of the Philosophy of, in Oxford Companion to Philosophy 468, 469 (Ted Honderich ed., 1995).

41 Finnis formulates the argument as follows:

Still, cannot descriptive analysis of law's character as an instrument proceed without evaluating the diverse purposes and uses to which the instrument is put? It seems not. For law's characteristic purport as obligatory and authoritative, like its purport as stipulating appropriate procedures and requiring fair trials and judgments based on truth, itself proposes an evaluation and critique of alternative social conditions (anarchy, arbitrary domination). How, then, could there be an adequately inward understanding or analysis of what characterizes diverse legal systems-an account showing why law deserves a place in any truly general account of human social life-without an understanding of the ways law's characteristic features themselves (even when being unjustly manipulated) manifest a critical evaluation of, and value-affirming constructive response to, the sorts of injustice or other lesion of human good which are inherent in lawlessness of every kind?

Finnis, supra note 40 , at 469 . In this position, Finnis's view converges with that of Lon Fuller. See, e.g., LON L. Fuller, The LAW IN QUeST OF ITSElf 41 (1940) (noting "the danger of attempting to deal with conceptual entities [in jurisprudence and political theory] without reference to the ends they are intended to serve"); see also Bix, supra note 3, at 22-31 (discussing Fuller's theory). A similar point is recognized by Neil MacCormick. See MacCormick, supra note 18, at 110-18 (discussing "the essential moral aspiration of law-giving").

42 Lon Fuller, in the context of discussing the later treatment of evil actions validated by Nazi law, wrote of "the dilemma as that of meeting the demands of order, on the one hand, and those of good order, on the other." See Fuller, supra note 21, at 657. From Fuller's other writings it seems clear that he might add that it is difficult to understand the idea of "order" without having a clear notion of what "good order" is. See generally Kenneth I. Winston, The Ideal Element in a Definition of Law, 5 LAw \& PHIL. 89 (1986) (discussing Fuller's approach to law).

43 On the use of teleological explanations, see generally LARrY Wright, TeleoLogical Explanations (1976). Not all teleological explanations are moral. For example, it may well be that one could not properly understand a game unless one understood the players' objectives, but (for most games) these objectives have no 
both classical and modern versions of natural law theory, where this aspirational or teleological approach (to morality and/or positive law) would be the one thread connecting older figures like Cicero ${ }^{44}$ and Aquinas ${ }^{45}$ with the variety of modern perspectives, including those of Russell Hittinger, ${ }^{46}$ Fuller, ${ }^{47}$ and Finnis. ${ }^{48}$

This is where, I believe, the issue between legal positivism and natural law theory may be finally joined, ${ }^{49}$ though I fear that the battle lines will never be entirely clear. Can one hold clearly to Raz's view that theory construction is evaluative but not moral?50 Or consider another position Raz has argued: that it is central to the nature of law that legal systems purport to be (legitimate) authorities, though in the real world few (if any) succeed. ${ }^{51}$ Can we construct a theory around the effort to be a legitimate authority, without building in a moral analysis of what it would take to be a legitimate authority (and what should follow when legal systems fall short of this standard)?

In part, these questions will turn on what it is legal theorists conceive themselves as doing. The natural law position seems relatively straightforward. The central question is how to live one's life, and the presence or absence of law and the presence or absence of good law will naturally affect such inquiries. The sociologist and historian also may have fairly clear notions of their projects, and each may have a clear and justified idea of why moral evaluation plays no part in their scientific (or quasi-scientific) gathering of data. ${ }^{52}$ However, the legal positivist has always claimed to be doing more from gathering data,

moral status or nature. Finnis's claim is not merely that law has a particular objective or aspiration, but also that this objective or aspiration is a moral one.

44 See Cicero, The Republic bk.3, at xxii.33, in De Re Publica, De Legibus (T.E. Page et al. eds. \& Clinton Walker Keyes trans., 1928) [hereinafter DE RE Publica]; Gicero, The Laws bk. II., at v.11-12, in DE RE PuBlicA, supra.

45 See Aquinas, supra note 8.

46 See HITTINGER, supra note 2.

47 See Lon L. Fuller, The MoraltTy of Law (rev. ed. 1969).

48 For a more detailed discussion of that connection, see Bix, supra note 3.

49 To clarify, there may be other ways of claiming that morality or moral evaluation is central to understanding law or doing legal theory, and therefore there are other forms of natural law challenges to legal positivism. One prominent example may be Dworkin's theory of law. See Brian Bix, Natural Law Theory, in A Companion to Philosophy of Law and Legal Theory 223, 234-37 (Dennis Patterson ed., 1996).

50 See supra note 9.

51 See RAz, supra note 9, at 215-16. Raz goes on to derive important aspects of his theory of law from this claim. See id. at 216-20.

52 I am aware that even here hermeneutic theorists and others have argued against a purely descriptive or otherwise value-free approach to history and the social sciences. See, e.g., Peter Winch, The Idea of a Social Science and Its Relation to PHILOSOPHY (1958) (arguing for a hermeneutic approach for social theory). 
while doing something different than telling people how to live. Yet the legal positivists have sometimes not been as clear, or as forthcoming, as they might be about the exact nature and status of their claims. ${ }^{53}$ When the theorists are clear, one can see how different their theories are, not only from the natural law theorists, but also from one another. For example, Raz's legal positivism offers a conceptual analysis of the (our) concept, "law."54 In contrast, Kelsen's legal positivism is a neo-Kantian effort to show what follows from the fact that people in fact think in a certain sort of way-legal-normatively. ${ }^{55}$ It may be that these sorts of projects, and others within the legal positivist camp, need not make room for moral teleology.

\section{CONCLUSION}

It used to be commonly believed that the disagreement between natural law theory and legal positivism was about the legal or moral validity of unjust official actions. Contemporary theorists in both camps have shown that this topic is in fact one in which agreement, rather than disagreement, predominates. Finnis has been active in this clarification. He has also been an important figure in discerning where the true dispute lies between natural law theory and legal positivism: he challenges the viability and value of descriptive or conceptual theories of law that do not partake of moral evaluation. Finnis has developed the argument that law can only be understood in a moral-based teleological analysis. This is a substantial challenge, one that hits at the core of legal positivism, and it will be interesting to see what responses legal positivism can offer. The response may come at a meta-theoretical level, grounded in statements about the different purposes of natural law and legal positivist theorizing and the different status of the claims being made.

53 I have considered some of these issues elsewhere at greater length. See Brx, supra note 10, at 9-28 (discussing issues concerning conceptual questions and jurisprudence); Brian Bix, On Description and Legal Reasoning, in RULES AND REASONING: Essays in Honour of Fred Schauer 7 (Linda Meyer ed., 1999).

54 See, e.g., Raz, supra note 9 (explicating ideas about conceptual analysis in legal theory, in the course of considering debates between Dworkin and Hart).

55 See Stanley L. Paulson, Introduction to KELSEN, supra note 22, at xvii, xxix-xlii (discussing Kelsen's neo-Kantian or regressive argument); see also Brx, supra note 10, at 51-59 (summarizing Kelsen's views). 